Indonesian Science Education Research

(ISER)

Available online https://jurnal.unimed.ac.id/2012/index.php/iser

ISSN Online: 2715-4653

\title{
IMPROVEMENT OF STUDENT PROBLEM-SOLVING ABILITIES THROUGH PROBLEM-BASED LEARNING MODELS
}

\author{
Rajo Hasim Lubis \\ Department of Physic Education Faculty of Mathematics and Science, Universitas \\ Negeri Medan, Medan-Indonesia \\ rajohasimlbs@unimed.ac.id
}

Accepted: December $5^{\text {th }}, 2020$. Published: December $31^{\text {th }}, 2020$

\begin{abstract}
The era of digitalization requires students to always be creative so as not to be out of date, one way is to improve problem-solving abilities. This research aims to improve students' problem-solving abilities by applying a problem-based learning model. The sample used was students of class X-1 as the experimental class and class X-2 as the control class selected using simple random sampling. This type of research is a quasi-experiment and the instrument of problem-solving ability used is in the form of an essay which consists of 8 questions. The results of the study concluded that the problem-solving ability in the experimental class using the problem-based learning model was better than conventional learning.
\end{abstract}

Keywords: problem-Solving Abilities, Problem-Based Learning Model, Physics 


\section{Introduction}

Education in Indonesia must be able to participate positively in this era of globalization, not wanting to be only objects and months of other nations. Therefore, we must prepare as early as possible to welcome this era, one alternative is to prepare human resources through the educational process. . The main problem that must be answered is what teaching models can improve the quality of human resources in facing the era of globalization. One of the best ways is to introduce and develop science and technology early in formal education because our students are human resources in the future (Nurkholis, 2013).

Education has an old paradigm, namely, the learning process runs in one direction only and is dominated by teachers. Teacher errors in choosing learning strategies can cause students to be less interested in learning so that it has an impact on reducing student motivation and activity during the teaching and learning process. This will also cause student learning outcomes that are not optimal. The results of an interview with a physics teacher stated that the average score of the students' daily tests was unsatisfactory. The lack of maximum student learning outcomes is caused by the low ability of students to solve problems (Fadillah, 2010; Hertiavi et al., 2010).

According to Trianto (2009), based on the results of research analysis on the low learning outcomes of students due to the dominance of the conventional learning process. In this learning, the classroom atmosphere tends to be teacher-centered so that students become passive. However, the teacher prefers to apply the model, because it does not require practical tools and materials, it is enough to explain the concepts in textbooks or references. Students are not taught learning strategies that can understand how to learn, think, and motivate themselves, even though these aspects are the key to success in learning.

Based on the researcher's preliminary observations at SMA Negeri 1 Hinai, it appears that the learning used in the classroom still tends to be teacher-centered, so that students become passive and have never used a problem-based learning model. Passive problems cause students' learning outcomes in class to be low. If we look at the physics test scores achieved by an average student of 55, it is still far below the Minimum Completion Criteria (KKM), which is 75 . From a practical point of view, learning is very rarely implemented due to very limited tools and materials, the majority of students only get material from the explanation. or theory so that it does not stimulate students' thinking to solve physics problems in everyday life or other words, the students' lack of problem-solving skills. The problem of the lack of students' problem-solving abilities can be seen from the initial observation by giving eight questions related to problem-solving only 2 out of 30 students passed the KKM score. The solution needed to overcome the above problems is by developing an effective learning model, which can attract students' attention, generate student motivation, actively involve students, and pay attention to student abilities.

The learning model that the researcher will apply is the problem-based learning model because problem-based learning is not designed to help teachers convey large amounts of information to students but problem-based learning is designed to help students develop thinking skills, problem-solving skills, and intellectual skills. the roles of adults by experiencing real or simulated situations, and becoming learners who become independent and autonomous (Arends, 2008).

Problem-based learning has been proven to improve students 'problemsolving abilities through previous researchers such as (Fatimah, 2013; Widjajanti, 2009) which stated that the Problem Based Learning Model was able to improve students' problem-solving abilities, but what distinguished previous researchers were that this research was applied to Physics subjects on Dynamic Electricity. Dynamic electricity was chosen as the material in the study due to the results of interviews with physics subject teachers that the Dynamic Electricity material got the lowest score in the previous semester. 


\section{Research Method}

This research was conducted at SMA Negeri 1 Hinai which is located at Sports Street, Hinai District, Langkat Regency, Indonesia. The sample in this study consisted of two classes, namely class X-2 as the control class and class $\mathrm{X}-1$ as the experimental class which was taken by using cluster random sampling technique. The variable in the study is the independent variable, namely the application of problembased and conventional learning models, the dependent variable is the student learning outcomes on dynamic electricity material.

This type of research is quasiexperimental research. The design of this research can be seen in Table 1 .

Tabel 1. Two Group Pretes - Posttes Design

\begin{tabular}{|l|l|l|l|}
\hline Group & Pretest & Treatment & Posttest \\
\hline Experimental & $\mathrm{T}_{1}$ & $\mathrm{X}$ & $\mathrm{T}_{2}$ \\
\hline Control & $\mathrm{T}_{1}$ & $\mathrm{Y}$ & $\mathrm{T}_{2}$ \\
\hline
\end{tabular}

Information :

$\mathrm{T} 1$ = Pretest is given to the experimental class and control class before treatment

$\mathrm{T} 2=$ Posttest given after treatment in the experimental class and control class

$\mathrm{X}=$ Teaching by applying a problem-based learning model

$\mathrm{Y}=$ Teaching by applying conventional learning models

$\mathrm{T} 1=\mathrm{T} 2$

The data collection technique was carried out before carrying out learning activities, carried out a preliminary test to determine the level of students' initial ability in dynamic electricity in the control class and the experimental class. After the dynamic electricity material was taught to students, a post-test was carried out to determine the students' problem-solving abilities in the control and experimental classes.

The research instrument used in this study was a student learning outcome test totaling 8 questions in the form of an essay test. Before conducting the research, the tests that have been compiled are tested for their validity.

The data obtained were then processed by data analysis techniques, namely calculating the mean of the pretest and posttest, normality test using the Lilliefors test, homogeneity test using the variance comparison test, hypothesis testing using the t-test

\section{Result and Discussion}

\section{Result}

The data described in this study include data on students' problem-solving abilities in the Dynamic Electricity material, which is given a different treatment, namely problem-based learning and conventional learning. Pretest data The problem-solving abilities of the experimental and control class students can be visualized in a diagram as shown in Figure 1.

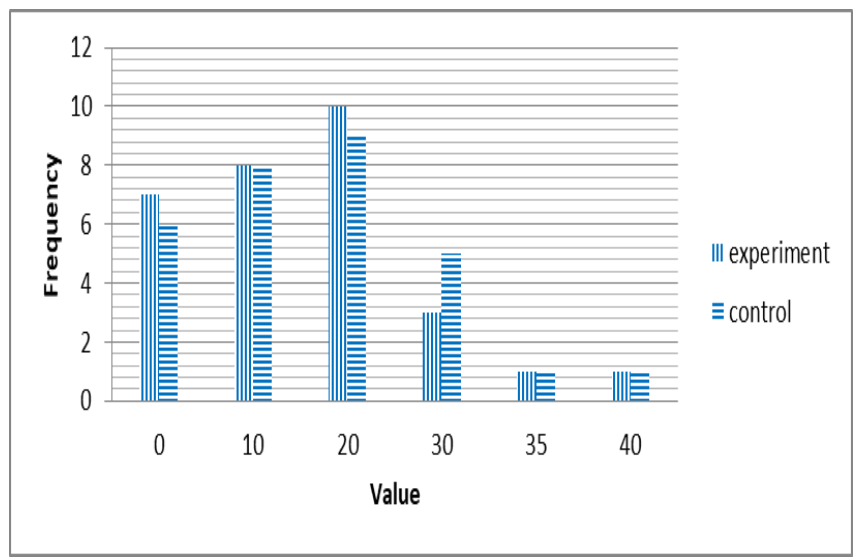

Figure 1. Pretest Experiment Class and Control Class

Posttest data The problem-solving abilities of the experimental and control class students can be visualized in a bar chart as shown in Figure 2

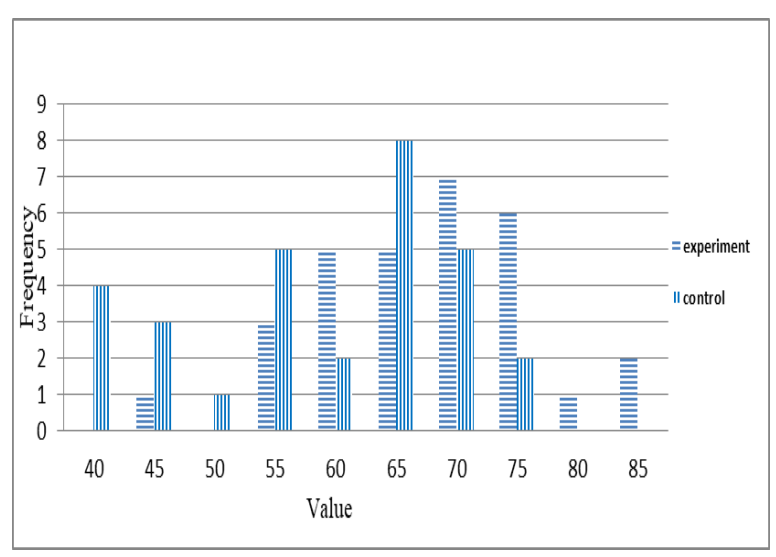

Figure 2. Posttest Experiment Class and Control Class 
For problem-solving abilities in this study starting from levels C3 (Apply), C4 (Analyze), C5 (Evaluate), C6 (Create). The data for the acquisition of the values of $\mathrm{C} 3$, $\mathrm{C} 4, \mathrm{C} 5, \mathrm{C} 6$ are more clearly visualized in the following bar chart:

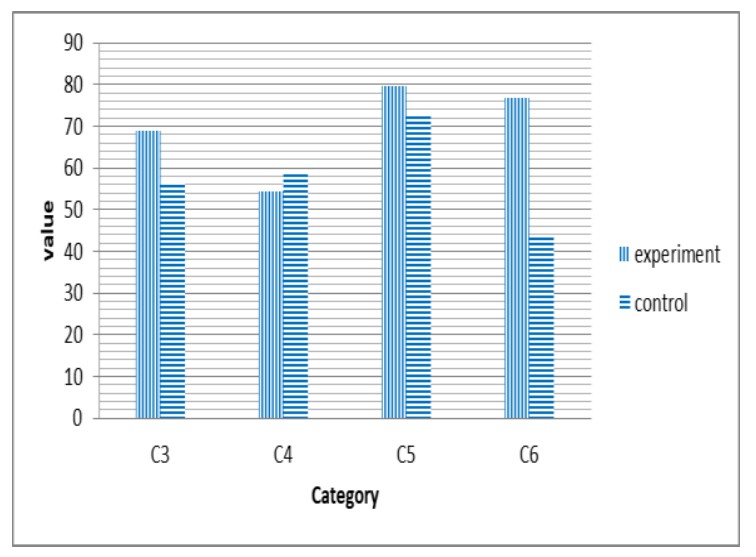

Figure 3. The category of students' problemsolving abilities in the experimental and control classes

Based on the bar chart above, the students' problem-solving ability in the experimental class was higher than in the control class. The reason is that in the experimental class students are required to work together in solving problems related to daily life and find their information related to the problem so that learning is more constructivist, while in the control class students only listen to information from explanations and work on problems so that learning be passive. However, in the $\mathrm{C} 4$ category, students in the control class had a higher average than the experimental class because at the second meeting there were 8 people from the experiment class who did not participate in learning due to extracurricular activities, thus affecting the average in the class.

In the C3-C6 categories, the highest difference in student problem-solving abilities in the C6 category (creating) or the highest problem difficulty level, with an average of 76.7 in the experimental class and 43.33 in the control class. This is due to the problem-based learning model has provided opportunities for students to explore collecting and analyzing data to solve problems so that students can think critically. Following the statement of Arends (2008), "PBL is not designed to help teachers convey large amounts of information to students but is designed primarily to help students develop thinking skills, especially higherlevel thinking skills (higher-level thinking skills).

\section{Discussion}

In the experimental class which was taught using the problem-based learning model, there was an increase in problemsolving abilities, where the pretest average score was 14.83 while the posttest average score was 67.5 . The problem-solving ability of students in the experimental class is because during the teaching and learning process using a problem-based learning model requires students to work together in solving problems related to everyday life and find their information related to the problem. Following constructivism learning theory states that students must find complex information on their own, check new information with old rules and revise it if the rules are no longer appropriate. For students, to truly understand and be able to apply knowledge, they have to solve problems, find everything for themselves, try-hard with ideas. Therefore, in the learning process students feel very happy with learning using models problem-based learning because students can feel for themselves the events related to everyday life, which are being studied.

In the control class that was taught using conventional learning, there was an increase in problem-solving abilities too, where the pretest average score was 16.17 while the post-test average score was 58.67. The increase in problem-solving ability in the control class was still lower when compared to the experimental class that uses a problem-based learning model. This is because conventional learning conveys information verbally to several students. This activity is centered on lecturers and unidirectional communication. In the conventional learning model, students learn more to listen to explanations in front of the 
class and carry out assignments if they are given practice questions to students. The conventional system of teaching carried out in the teaching and learning process is by using the lecture, question, and answer, and demonstration method, so that students feel bored, passive, and easily forget.

There are several advantages of the problem-based learning model; 1) Increase learning motivation because students are actively involved in the learning process; 2) Students are trained to relate the problems studied with everyday life so that students are required to learn to discover; 3) Students are deeper into higher-order thinking, such as analyzing, solving problems that occur in everyday life, finding, evaluating, working together, showing good communication.

Besides, problem-based learning models can provide opportunities for students to explore, collect, and analyze data to solve problems, so that students can think critically, analytically, systematically, and logically in finding alternative problemsolving. Students, in this case, are active and enthusiastic to work with friends in the group in solving problems that have been given by the researcher. Students are also interested and active when discussing and expressing different opinions during discussions between groups.

In the student orientation stage of the problem (first), the researcher motivates students by providing learning objectives that will be achieved by students and at this stage, the researcher gives problems to students by showing two different simple series. At the stage of organizing students to learn (second), the researcher provides the subject matter that is studied then forms study groups and conducts experiments (experiments). At the stage of individual and group investigation (third), the researcher guides each student to collect information to solve problems and conduct experiments (experiments) once again. At the stage of developing and presenting artifacts and exhibits (fourth), the researcher helps each group solve and answer all existing problems, and present the results of the group discussions that have been prepared, then the other groups are allowed to provide opinions or input. At the stage of analyzing and evaluating the process of overcoming the problem (fifth), the researcher assists students in reviewing problem-solving following the learning objectives and reinforces solving the problem and at this stage, the researcher makes an evaluation test to determine student understanding.

The results of this study are in line with previous research as examined by (Kharida, 2009), which states in the results of their research that there is an increase in the average cognitive learning outcomes of students who are taught by problem-based learning models. (Yasa, 2007) shows that students' basic physics competencies can be improved by using problem-based strategies. (Akinoğlu \& Tandoğan, 2007) show that the problem-based active learning model had positively affected students' academic achievement and their attitudes towards the science course. (Tika, 2008), the PBL model can significantly improve students' understanding of physics concepts.

Although the problem-based learning model has made better learning outcomes compared to conventional learning, there are several obstacles in conducting research; 1) Researchers are not maximized in managing time so that all syntax is less effective when implementing the learning process; 2) There are still more students because this model has never been applied in that school.

\section{Reference}

Akinoğlu, O., \& Tandoğan, R. Ö. (2007). The effects of problem-based active learning in science education on students' academic achievement, attitude and concept learning. Eurasia Journal of Mathematics, Science and Technology Education. https://doi.org/10.12973/ejmste/75375

Fadillah, S. (2010). Kemampuan Pemecahan Masalah Matematis dalam Pembelajaran Matematika. Prosiding Seminar Nasional Penelitian, Pendidikan Dan Penerapan MIPA, Fakultas MIPA, Universitas Negeri Yogyakarta.

Fatimah, F. (2013). KEMAMPUAN KOMUNIKASI MATEMATIS DAN 


\author{
PEMECAHAN \\ MASALAH \\ MELALUI PROBLEM BASED- \\ LEARNING. Jurnal Penelitian Dan \\ Evaluasi Pendidikan. \\ https://doi.org/10.21831/pep.v16i1.111 \\ 6
}

Hertiavi, M. A., Langlang, H., \& Khanafiyah, S. (2010). PENERAPAN MODEL PEMBELAJARAN KOOPERATIF TIPE JIGSAW UNTUK PENINGKATAN KEMAMPUAN PEMECAHAN MASALAH SISWA SMP. JPFI, 6(1), 53-57.

https://doi.org/https://doi.org/10.15294/ jpfi.v6i1.1104

Kharida, L. . (2009). Penerapan Model Pembelajaran Berbasis Masalah Untuk Peningkatan Hasil Belajar Siswa Pada Pokok Bahasan Elastisitas Bahan. Jurnal Pendidikan Fisika Indonesia, 5, 83-89.

Nurkholis. (2013). PENDIDIKAN DALAM UPAYA

MEMAJUKAN

TEKNOLOGI Oleh: Nurkholis Doktor
Ilmu Pendidikan, Alumnus Universitas Negeri Jakarta Dosen Luar Biasa Jurusan Tarbiyah STAIN Purwokerto. Jurnal Kependidikan, 1(1), 24-44. http://ejournal.iainpurwokerto.ac.id/ind ex.php/jurnalkependidikan/article/down load/530/473/

Tika, I. K. (2008). Penerapan Problem Based Learning Berorientasi Penilaian Kinerja Dalam Pembelajaran Fisika Untuk meningkatkan Kompetensi Kerja Ilmiah Siswa. Jurnal Pendidikan Dan Pengajaran UNDIKSHA, 3, 648-700.

Widjajanti, D. B. (2009). Kemampuan Pemecahan Masalah Matematis Mahasiswa Calon Guru Matematika: Apa dan Bagaimana Mengembangkannya. Seminar Nasioanal FMIPA.

Yasa, P. (2007). Strategi pembelajaran berbasis masalah untuk meningkatkan kompetensi dasar fisika siswa kelas viii SMP N 2 Singaraja. Jurnal Pendidikan Dan Pengajaran UNDIKSHA, 3, 622637. 